\title{
Turismo e urbanização-metropolização no litoral do Nordeste e Sul brasileiro:
}

\section{Fortaleza e Florianópolis}

\author{
Tourism and metropolitan-urbanization at the brazilian Northeast and South coasts: Fortaleza and \\ Florianópolis cities
}
Turismo y urbanización-metropolización en la costa del Noreste y Sur de Brasil: Fortaleza y
Florianópolis

Recebido: 02/09/2021 | Revisado: 09/09/2021 | Aceito: 11/09/2021 | Publicado: 13/09/2021

\author{
Ícaro Coriolano Honório \\ ORCID: https://orcid.org/0000-0002-0338-7779 \\ Instituto Federal de Educação, Ciência e Tecnologia do Ceará, Brasil \\ E-mail: icarocoriolano@hotmail.com \\ Isa de Oliveira Rocha \\ ORCID: https://orcid.org/0000-0001-9840-0595 \\ Universidade do Estado de Santa Catarina, Brasil \\ E-mail: isa.rocha2007@gmail.com
}

\begin{abstract}
Resumo
O processo de urbanização nos municípios de Fortaleza (Ceará/Brasil) e Florianópolis (Santa Catarina/Brasil) teve o turismo litorâneo como um dos seus principais fatores de desenvolvimento. Esta pesquisa, de caráter qualitativo e de revisão teórico-temática, tem como objetivo discutir o processo histórico e contemporâneo da urbanização turística nos municípios de Fortaleza e Florianópolis. Concluiu-se que é necessário pensar e planejar sobre as implicações que podem ocorrer diante da alteração do espaço motivada pelo turismo ou por qualquer outra atividade econômica.
\end{abstract}

Palavras-chave: Turismo; Urbanização; Metropolização; Litoral.

\begin{abstract}
The urbanization process in Fortaleza (Ceará/Brazil) and Florianópolis (Santa Catarina/Brazil) cities had the coastal tourism as one of the main factors of their development. This profile-qualitative and theoretical-theme proofreading survey, aims to discuss the historical and contemporary process of touristic urbanization in Fortaleza and Florianópolis municipalities. It was concluded that it is mandatory to plan and to think about the implications that might occur in the face of the gap alteration motivated by tourism or by any other financial activity.
\end{abstract}

Keywords: Tourism; Urbanization; Metropolization; Coast.

\section{Resumen}

El proceso de urbanización en los municipios de Fortaleza (Ceará/Brasil) y Florianópolis (Santa Catarina/Brasil) tuvo al turismo costero como uno de sus principales factores de desarrollo. Esta investigación con carácter cualitativo y de revisión teórico-temática tiene como objetivo discutir el proceso histórico y contemporáneo de la urbanización turística en los municipios de Fortaleza y Florianópolis. Se concluyó que es necesario pensar y planificar las implicaciones que pueden ocurrir ante la alteración de los espacios motivada por el turismo o cualquier otra actividad económica.

Palabras clave: Turismo; Urbanización; Metropolización; Costa.

\section{Introdução}

O espaço caracteriza-se como meio, condição e produto das práticas humanas contemporâneas. Experimenta-se, atualmente, um momento do urbano que já não é mais tão delineado pelas lógicas espaciais da indústria, pois a preponderância de uma economia baseada nesse setor produtivo deu lugar àquela mais ligada aos serviços. Assim, as cidades capitalistas trazem essa complexidade e algumas delas passaram, nos últimos anos, a serem transformadas e ressignificadas com o objetivo de produzir e adaptar o espaço urbano para atividades de lazer e turismo. As cidades foram, aos poucos, transformando-se em mercadorias nas quais os espaços são consumidos, estando, então, ligadas à condição geral do processo de reprodução do 
capital. (Ferreira, Rua \& Matos, 2014; Correa, 2016).

O turismo enquanto processo utiliza os recursos e os espaços utilizados pelos residentes e nem sempre é associado a impactos positivos, havendo, também, impactos negativos, caso o seu desenvolvimento no espaço não seja adequado. O que significa que a atividade turística tem a responsabilidade de efetivar um desenvolvimento sustentável, minimizando, assim, os impactos negativos (Moleiro, 2020).

Para Santos (2006), a expansão da urbanização e o aumento da importância do fenômeno urbano são, hoje, a base para mais racionalização, que se torna mais presente à medida que se aumenta a articulação com o campo tecnicizado e modernizado e a interdependência entre as cidades. Nestas, as atividades modernas tendem, cada dia mais, a ser o meio dos horários, dos relógios, das normas, dos regulamentos. Isso não se estende apenas à atividade industrial, mas também aos serviços, como os que se relacionam à atividade turística: hospedagem, alimentação, entretenimento, dentre outros, configurando-se, assim, o turismo urbano.

Segundo Pérez (2018), o turismo urbano se posicionou como um dos maiores segmentos da economia mundial, sua capacidade de gerar emprego e seu efeito multiplicador sobre outros setores produtivos são fatores que desenvolvem uma abordagem de análise da realidade do turismo, que servirá como ponto de partida para o desenvolvimento de políticas adequadas por parte dos agentes públicos e privados desse setor. Nesse contexto, fica evidente o interesse dos governos e da iniciativa privada em aproveitar as oportunidades geradas pelo turismo como ferramenta de desenvolvimento econômico global e, ao mesmo tempo, despertando preocupação com a preservação e revalorização de áreas urbanas de valor histórico e patrimonial, aumento e diversificação de eventos culturais, políticas de reordenamento do uso do solo e investimentos em infraestrutura.

Para Allis e Vargas (2015, p. 500): "De maneira geral, o estudo do turismo urbano busca concatenar condicionantes e particularidades do turismo praticado nas cidades, principalmente nas grandes aglomerações, onde as motivações específicas das visitas não são claras (à diferença dos resorts litorâneos ou em cidades antigas com núcleo histórico característico)”.

Associado ao fenômeno do turismo urbano, a urbanização turística, no Brasil, é um processo observado, sobretudo nas últimas três décadas, decorrente do crescimento do segmento do turismo de sol e praia ao longo da zona costeira do país, rearranjando sua organização socioespacial. Podem ser destacadas duas dimensões do desenvolvimento recente do turismo no Brasil. A primeira dimensão é a estruturação espacial promovida com a participação dos governos nos três níveis da federação, criando condições favoráveis para atração de investimentos privados por meio da implantação de infraestruturas urbanoregionais (aeroportos, rodovias, saneamento básico, eletrificação, reformas urbanas, etc.) e incentivos fiscais. A segunda dimensão está relacionada às ações dos atores privados que investiram na implantação de equipamentos turísticos como hotéis, resorts, parques temáticos, condomínios de segunda residência, etc. (Silveira \& Rodrigues, 2015).

A dinâmica da produção do espaço urbano litorâneo ocorre no contexto da sociedade capitalista. O imaginário social de aproveitamento das áreas litorâneas influencia a produção do espaço urbano nesses ambientes; a imagem do "lugar paradisíaco" fica renegada às pressões dos agentes produtores do espaço urbano. Dessa forma, os espaços de praia vão se transformando em espaços urbanos consolidados. A grande motivação da construção do imaginário social de sol e praia vai sendo substituída pela demanda dos espaços urbanos, incluindo serviços, comércio e lazer homogeneizante, refletindo os efeitos do atual período econômico mundial (Correa, 2016).

Há de se falar também na dinâmica do processo de metropolização que, conforme apontam Ferreira, Rua e Mattos (2014), tem contribuído para a transformação do mercado do solo urbano, que passa por intensa valorização e chega a gerar especulação imobiliária. Essa elevação de preços faz com que as construtoras busquem áreas mais distantes para construir, agregando novas áreas à dinâmica de mercado metropolitano, o que provoca a extensão indefinida da área urbana, invadindo, inclusive, os limites de área rural, intensificando-se a capitalização do campo associada ao desenvolvimento do setor de 
serviços, como o turismo, e de tecnologia de comunicação e informação. O Brasil, assim, conforme Alves et al. (2021, p. 3), "abandonou um arranjo litorâneo, esparso e descentralizado e passou a incorporar localidades urbanas de porte considerável em pontos estratégicos de todo o território".

É preciso pontuar, também, que com a crescente busca por emprego, a cidade passa a ser vista como uma real oportunidade para se obter melhores condições de vida, atraindo grandes massas populacionais, fazendo com que as metrópoles se expandam para além dos limites originais e ganhem áreas periféricas (Verde et al., 2020).

Santos (1993, pp. 75-76) diz que as Regiões Metropolitanas têm como pontos comuns dois elementos essenciais:

a) são formadas por mais de um município, com o município núcleo - que lhes dá o nome - representando uma área bem maior que as demais;

b) são objeto de programas especiais, levados adiante por organismos regionais especialmente criados, com a utilização de normas e de recursos em boa parte federais. São, na verdade, regiões de planejamento, onde, todavia, o que é feito não atende à problemática geral da área, limitando-se a aspectos setoriais.

Conforme o estudo "Regiões de Influência das Cidades 2018", publicado pelo IBGE no ano de 2020, as Metrópoles se subdividem em três níveis: Grande Metrópole Nacional, Metrópole Nacional e Metrópole, estando Fortaleza (CE) e Florianópolis (CE) ligadas à última classificação. A média populacional das Metrópoles é de 3 milhões de habitantes, sendo a mais populosa Belo Horizonte (MG), com 5,2 milhões, e as menos populosas Florianópolis (SC) e Vitória (ES), com 1 milhão e 1,8 milhão de habitantes, respectivamente.

Esta pesquisa tem como objetivo discutir o processo histórico e contemporâneo da urbanização turística nos municípios de Fortaleza (CE) e Florianópolis (SC).

\section{Metodologia}

Esta pesquisa caracteriza-se como qualitativa e de revisão teórico-temática. Conforme Minayo (2001, p. 21), a pesquisa qualitativa "trabalha com o universo de significados, motivos, aspirações, crenças, valores e atitudes, o que corresponde a um espaço mais profundo das relações, dos processos e dos fenômenos que não podem ser reduzidos à operacionalização de variáveis". Luna (1988, p. 74) diz que "o referencial teórico de um pesquisador é um filtro pelo qual ele enxerga a realidade, sugerindo perguntas e indicando possibilidades".

A revisão teórico-temática considera livros, sites, teses, dissertações e artigos científicos referentes às temáticas de turismo e geografia. As consultas às teses e dissertações, que incluem a temática desta proposta de pesquisa, estão em bancos de dados de universidades. Os artigos científicos têm origem em banco de dados Periódicos Capes e em revistas científicas especializadas da área de turismo e geografia.

\section{Caracterização Histórica}

\subsection{Fortaleza}

As intervenções antrópicas históricas na faixa litorânea de Fortaleza causaram transformações significativas não apenas no processo de urbanização, mas na relação da cidade com a sua orla marítima. A faixa litorânea de Fortaleza caracteriza-se por uma elevada complexidade socioambiental, morfológica, econômica e cultural, visto que a ocupação não se efetuou de forma homogênea, obedecendo a um processo de urbanização desigual da cidade (Paiva, 2014).

Conforme Paiva (2014), no final do século XIX e início do século XX, a ocupação da faixa de praia em Fortaleza se dá primeiramente pela população de menor poder aquisitivo, formada principalmente por pescadores e migrantes sertanejos, que não usufruíam das melhorias do processo de urbanização da cidade no período, possuindo habitações precárias. A faixa 
litorânea caracterizava-se espacialmente pela presença de armazéns, galpões, do comércio atacadista, da alfândega, os quais davam suporte à atividade portuária.

Posteriormente, ainda segundo Paiva (2014), a ocupação litorânea por aglomerações espontâneas favelizadas acentuou-se a partir da década de 1930, sendo alguns trechos do litoral incorporados para tal fim, como é o caso do Pirambu (1932), na faixa litorânea oeste, e, depois, no Mucuripe, localizado no extremo leste, associados à construção do ramal ferroviário Parangaba-Mucuripe para viabilizar o porto recém-construído. Assim, surgiram favelas ao longo do ramal ferroviário e nas dunas da zona portuária.

As novas práticas marítimas, influenciadas pelos hábitos europeus e associadas aos banhos de mar terapêuticos (substituídos com o tempo pelos esportes náuticos), começaram a gerar tímido movimento de urbanização das zonas de praia. A urbanização litorânea de Fortaleza foi inicialmente motivada pela vilegiatura, anterior ao fenômeno do turismo, que desde 1920 - e em seu ápice nos anos 1950 e 1960 - produziram espaços destinados ao lazer, em destaque a Praia de Iracema e a Beira-Mar em Fortaleza (Araújo, 2011; Dantas, 2011; Paiva, 2014).

Desde 1950, já se registravam turistas em Fortaleza, e principalmente a partir de 1953, com a construção do calçadão da Beira-Mar, quando hotéis e pousadas foram construídos em seu entorno, tornando a área como uma das mais importantes nas atividades de lazer e recreação da cidade. Em virtude da concentração desses serviços, a praia torna-se ponto de encontro da elite intelectual boêmia fortalezense (Araújo, 2011; Dantas, 2011; Paiva, 2014).

A partir da implementação do Plano Diretor de Desenvolvimento Urbano de Fortaleza, datado de 1962, orienta-se o crescimento da cidade para o litoral, com a construção da Avenida Beira-Mar (1963), integrando as zonas de praia à cidade, ora como equipamento público de lazer, ora como lugar de habitação das classes abastadas (Dantas, 2011; Paiva, 2014).

Souza (2007, pp. 34-35) discute que:

O Plano Diretor de Desenvolvimento Urbano de Fortaleza - PDDU FOR -, inicialmente disciplinado pela Lei $\mathrm{n}^{\circ}$ 5.122 de 1979, criou um ambiente extremamente favorável à verticalização do espaço na Avenida Beira Mar, se tornando a região saturada de condomínios de luxo, além de hotéis, tornando o local sensivelmente valorizado no campo da especulação imobiliária.

Nessa altura do processo de urbanização da cidade, a Praia do Meireles, onde se localiza a Avenida Beira-Mar, constituía não somente um território de concentração de atividades de lazer privado dos clubes, residências de veraneio e das práticas de recreação, mas uma área que se valorizava gradativamente como local privilegiado da habitação da elite em função da expansão urbana em direção ao mar, proveniente do prolongamento da malha urbana ligado à Praia de Iracema e à Aldeota (Paiva, 2014).

Cabe destacar o trecho de Dantas (2011, pp. 59-60):

Na década de 1970, após a urbanização das praias de Iracema e do Meireles, a cidade volta-se para o mar. As políticas públicas que referendam as ações privadas - com a construção de hotéis, de pousadas, de restaurantes, de barracas e de estações aquáticas, bem como os loteamentos e arranha-céus que suscitam a verticalização da zona leste de Fortaleza (principalmente Aldeota e Meireles) - constroem uma cidade litorânea, capaz de responder à demanda crescente por espaços de lazer e turístico. A primeira, relativa ao lazer, resulta de demanda interna de uma classe privilegiada que se amplia gradativamente em face das classes menos abastadas. A segunda, relativa ao turismo, origina-se de demanda externa, que aumenta no transcorrer dos anos.

Durante toda a década de 1990, a Praia de Iracema representou o palco das intenções de promoção do desenvolvimento turístico do Ceará e de Fortaleza, por parte dos interesses políticos envolvidos. Essas ações foram concretizadas com a construção do Centro Dragão do Mar de Arte e Cultura, em 1999, que teve a atratividade reduzida com o tempo pela falta de integração com as intervenções na orla, criando-se nessa área oportunidades para a exploração sexual no 
turismo (Paiva, 2014).

Nesse processo de urbanização litorânea, Paiva (2014, p. 05) discorre que "o adensamento dos terrenos defronte à orla, a diversificação dos usos, a ocupação do espaço público pelo privado, o lançamento de efluentes nas galerias pluviais e o lixo colaboraram para comprometer a balneabilidade da praia", atualmente com trechos próprios para banho por iniciativa de despoluição das águas marítimas efetuada pelo poder público.

A Praia do Futuro foi a última zona de praia incorporada à zona urbana de Fortaleza. Localizada na zona leste do litoral fortalezense, entre o Porto do Mucuripe e a foz do Rio Cocó, teve seus terrenos valorizados em função da construção do porto, a partir da década de 1940. Na década de 1950, toda a faixa junto à praia foi loteada por Antônio Diogo, então proprietário de toda a área, e que, a exemplo de outras praias, incorporou-se ao espaço urbano, ora como periferia de zona portuária (o Porto do Mucuripe), ora como lugar ocupado para responder à demanda das classes abastadas que frequentavam a praia do Meireles (Dantas, 2011; Paiva, 2014).

Entre os anos 1960 e 1980, a urbanização da Praia do Futuro se deu vagarosamente e ainda hoje não se consolidou. A partir da década de 1980, esboçou-se um processo de ocupação da praia pela habitação da classe média, de residências unifamiliares e edifícios multifamiliares, porém, fatores naturais desta zona de praia (fortes ventos e maresia) prejudicaram o processo de ocupação efetivo da praia nos fins da década de 1980. Datam também deste período os primeiros investimentos na implantação de infraestrutura viária com o melhoramento dos acessos, como foi o caso da ampliação da Av. Santos Dumont, em 1976, até a Praça 31 de Março, e a construção do calçadão da Praia do Futuro com o alargamento da Avenida Zezé Diogo, paralela à praia (Paula, 2012; Paiva, 2014).

Araújo (2011) discute que, nos anos 1980, a atividade turística cresceu mundialmente e a cidade de Fortaleza seguiu no mesmo sentido. Fomentado por políticas públicas, propaganda e marketing, o turismo ultrapassa os limites de Fortaleza e consolida-se na metrópole ao influenciar outros municípios, como Aquiraz e Caucaia. Assim, criaram-se os espaços turísticos metropolitanos de Fortaleza, concebidos pela expansão de espaços de lazer da metrópole, privilegiando as zonas litorâneas.

Nessa década, o estado põe em prática uma política pública de planejamento territorial, estimulada pelo PRODETUR$\mathrm{CE}$, que reforça as conexões de Fortaleza com as zonas de praia, contribuindo para a consolidação de novos fluxos na rede urbana e que privilegiam as relações da capital com o litoral como mercadoria turística, além das práticas de veraneio. Fortaleza transforma-se, então, em ponto de chegada e distribuição de fluxos turísticos, especialmente com a construção do Aeroporto Internacional e de vias de circulação terrestre, como a CE 040, da capital até Fortim, e a CE 261, de Fortim a Icapuí. Os investimentos privados também se inserem nesse contexto. A hotelaria transfere suas atividades do Centro de Fortaleza para os bairros litorâneos, principalmente a Avenida Beira-Mar (Dantas, 2011).

Por fim, Araújo (2011) e Dantas (2011) argumentam que, com a implementação de política de marketing, a partir da década de 1990 até os dias atuais, fortaleceu-se o quadro simbólico representativo de uma sociedade litorânea-marítima, com transformações que caracterizam a transição de uma sociedade interiorana para uma sociedade marítima, criando-se novas relações com o meio ambiente por meio da valorização das zonas de praia. Entretanto, torna-se necessário refletir sobre a forma de se apropriar destes espaços e respeitar os limites impostos pela natureza frágil das zonas de praia e as comunidades litorâneas que aí habitam.

\subsection{Florianópolis}

O processo de urbanização de Florianópolis está associado ao contexto de ascensão e decadência da pequena produção mercantil açoriana, assim como na divisão social e territorial do trabalho ligada ao desenvolvimento do capitalismo. A expansão dos núcleos urbanos localizados na faixa litorânea catarinense tem como principal fator o crescimento econômico dessas localidades baseado na industrialização, na prestação de serviços e/ou nas atividades decorrentes do turismo. A procura 
do interior da Ilha de Santa Catarina e de suas praias teve início a partir das praias mais próximas ao centro da cidade; depois, buscou as praias continentais e, por fim, dirigiu-se às praias mais distantes das baías norte e sul e às praias oceânicas situadas nas costas norte e ao leste (Bastos, 2000; Pereira, 2010; Reis, 2010).

Florianópolis apresenta, a partir da década de 1960, uma acelerada expansão de vários setores ligados à prestação de serviços, com a criação de inúmeros órgãos e repartições estaduais e federais, como foi o caso da Universidade Federal de Santa Catarina e da sede da ELETROSUL, transferida para a capital catarinense, principal centro político e administrativo de Santa Catarina. Somado a esses fatores, há que se considerar a expansão, nas últimas décadas, das atividades ligadas ao turismo, que tem contribuído para a aceleração das transformações socioespaciais da capital e de outras cidades localizadas no litoral catarinense (Bastos, 2000; Pereira, 2010; Reis 2010; Mamigonian, 2011).

Outra contribuição para o desenvolvimento da cidade nesse período, conforme aponta Campos (2009), foi a construção das pontes Colombo Machado Sales e Pedro Ivo Campos. Os aterros das Baías Sul e Norte também viabilizaram a expansão urbana, além dos viadutos, ruas e vias duplas construídos na Ilha, facilitando o acesso às praias e agilizando a mobilidade na cidade.

Nessa década, a modernização dos acessos às praias voltadas para o escoamento da produção de pescado favoreceu a expansão da atividade turística. Por outro lado, a multiplicação dos loteamentos e empreendimentos imobiliários, muitos voltados para o turismo de segunda residência, como no caso de Canasvieiras, impediam as comunidades pesqueiras de chegar até as praias, através de maracutaias legais, como a privatização das terras de uso comum (Bastos, 2000).

Conforme Machado (2000) e Reis (2010), por meio dessa movimentação turística, iniciada nos anos 1950, com a expansão de usos turísticos e segunda residência para as classes médias, a cidade se expandiu por toda a Ilha, rompendo o isolamento do interior insular, transformando as antigas localidades agrícolas e pesqueiras em balneários. Posteriormente, além da ocupação sazonal, muitos desses balneários passaram a abrigar, também, número expressivo de moradias permanentes.

Antes mesmo da dinamização das atividades turísticas em Florianópolis pelo consumo das áreas marinhas, as elites florianopolitanas já efetuavam suas práticas de veraneio em locais como Balneário Camboriú, que serviu de espelho para a capital catarinense. Assim, surgiram as primeiras infraestruturas urbano-turísticas em vários locais da Ilha de Santa Catarina, aumentando cada vez mais o fluxo do "turismo de massa", não apenas de catarinenses, mas também de gaúchos, entre os anos 1960 e 1970. Desde então, o turismo começou a influenciar processos de urbanização no município de Florianópolis e a chamar atenção de vários segmentos para sua exploração, dinamizando a conjuntura socioeconômica local (Machado, 2000).

A partir dos anos 1980, deu-se início à discussão de projetos para incrementar o turismo na Capital do Estado. Estratégias de marketing foram lançadas para vender os atrativos do local, com a espetacularização da cultura da Ilha. O homem açoriano - "manezinho da ilha" - começou a retratar o passado da cidade, o marco referencial do povo. Florianópolis passou a ter novos ares para tornar-se atrativa e lucrar com a indústria do turismo (Zanela, 1999). Nessa década, segundo Machado (2000), as atividades ligadas à construção civil e a empreendimentos hoteleiros despontaram entre as que mais buscaram abocanhar o máximo da fatia do turismo para geração de rendas, particularmente nos locais de balneários.

Zanela (1999) discorre que nos anos posteriores às enchentes de 1983 no estado, o governador Amin lançou o lema "Venha visitar o que você ajudou a salvar", dentre outras medidas, como estratégia para reativar o turismo no estado. Cláudio Ávila da Silva, Prefeito da capital, compactuou com as ideias do Governador do estado e, a partir de então, aconteceu a união Governo/Prefeitura no reinventar e repensar estrategicamente as políticas públicas do estado. Foi nessa busca por soluções que Ávila passou a incentivar a "vocação turística de Florianópolis" em seu discurso. Assim, as prioridades do prefeito a partir daquele momento passaram a se voltar para as políticas públicas de turismo, onde obras são planejadas, mandato após mandato, assumindo diferentes representações ao sabor das competições políticas.

O Plano de Desenvolvimento Turístico-PDT elaborado pelo Instituto de Planejamento Urbano de Florianópolis - 
IPUF, no início da década de 1980, voltado para o reconhecimento e ordenação do uso do solo na região do Aglomerado Urbano - AUF, foi executado seguindo orientações metodológicas do Conselho Nacional de Desenvolvimento Urbano CNDU, contando na ocasião com apoio de técnicos alemães por meio de convênio celebrado pela Prefeitura de Florianópolis, o Banco Interamericano de Desenvolvimento-BIRD e órgãos alemães. Do PDT emergiram várias ações públicas, como o "Plano Diretor dos Balneários" (1985), dando-se um grande pontapé na nova fase de sistematização de informações e despertando entre segmentos sociais as facilidades de atuação em iniciativas privatizantes (Machado, 2000).

No decorrer dessa trajetória, Rizzo (2013) discute que a formação do Mercosul, em 1991 (Tratado de Assunção, 26 de março de 1991), envolvendo a Argentina, o Brasil, o Paraguai e o Uruguai, fez com que os estados do sul do Brasil - Paraná, Santa Catarina e Rio Grande do Sul - buscassem tirar vantagens dessa relação comercial pela proximidade com os demais integrantes, principalmente os grandes aglomerados urbanos, como Buenos Aires, Montevidéu, Assunção, como forma de atrair investimentos diretos, gerando uma competição entre esses estados.

Florianópolis, que não tinha conseguido alcançar o mesmo nível de desenvolvimento que as duas outras capitais do Sul nos períodos anteriores, também haveria de entrar nessa competição, explorando suas atratividades ou criando-as. Na virada da década de 1980 para a de 1990, nas administrações de Esperidião Amin (1989/1990) e de Bulcão Viana (1990/1993), os elaboradores das políticas locais lançaram a ideia de que Florianópolis teria uma vocação natural voltada para as indústrias do turismo e de alta tecnologia, consideradas como indústrias limpas, e, dessa forma, apropriadas para o contexto ambiental da Ilha de Santa Catarina (Rizzo, 2013).

A ideia surgiu obviamente porque já havia um desenvolvimento engatilhado desses setores na cidade. O número de visitantes, principalmente advindos da Argentina, durante a década de 1980, crescia significativamente, sobretudo no verão, e surgiam empresas de tecnologia que prestavam serviços às estatais de telefonia e energia. Para esse setor, a política sugerida foi a de criação de parques tecnológicos, tendo sido propostos três: o Parque Beta, no Campeche; o Parque Alfa, no bairro do Saco Grande; e o Parque Gama, no município de São José. Com a criação do Mercosul, em 1991, Florianópolis passou a se intitular "a capital turística do Mercosul", sendo que uma placa com esse lema, colocada na principal via de acesso à Florianópolis, indicava a chegada na cidade - imagem que contrastava com a favela Chico Mendes, ao seu lado (Rizzo, 2013).

Machado (2000, p. 177) acrescenta que "a presença de brasileiros - sobretudo paulistas, gaúchos e paranaenses também ampliou os fluxos naquela década e ajudou no processo de multiplicação de formas de demandas de mercadorias, no espaço local/regional."

$\mathrm{Na}$ ideia de reintegrar o potencial existente para que o turismo trouxesse maiores benefícios à cidade e à população, foi organizado, no ano de 1994, o primeiro Fórum Nacional de Planejamento Turístico da Grande Florianópolis. Questões que foram discutidas durante $\mathrm{o} 1^{\mathrm{o}}$ Fórum consideraram principalmente a sustentabilidade da atividade turística e a profissionalização do setor. Paralelamente aos debates, soluções práticas foram tomadas, sendo instalada uma Bolsa de Negócios e Investimentos, promovida pelo Banco Regional de Desenvolvimento - BRDE, visando estimular o surgimento de novos projetos turísticos na região (Zanella, 1999).

No final dos anos 1990, conforme Machado (2000), Florianópolis (junto a Balneário Camboriú) já se destacava entre os principais destinos de turistas estrangeiros, configurando-se entre os principais polos regionais que vinham estimulando o desenvolvimento urbano-turístico na faixa litorânea catarinense, fenômeno que se observa até os dias atuais, gerando-se possibilidades de conexões e inserção local no contexto da globalização contemporânea. 


\section{Caracterização contemporânea}

\subsection{Fortaleza}

A cidade de Fortaleza é o principal destino turístico do Ceará, recebendo grande parte dos turistas e caracterizando-se como centro receptor e distribuidor de fluxos turísticos, concentrando $20 \%$ de todos os empreendimentos turísticos do Ceará, dinâmica favorecida pelos pesados investimentos estatais e privados. Esse fator se deve à boa oferta de meios de hospedagem, além de sólida infraestrutura, com centros financeiros, administrativos, restaurantes, shoppings, bares, bancos entre outros serviços, sem contar com o Aeroporto Internacional de Fortaleza, que vem passando por constantes expansões para a ampliação de sua capacidade (Araújo, 2011; Araújo, 2016).

Barbosa e Paula (2020) afirmam que, com a instalação do Hub aéreo da Air France-KLM e da Gol, ampliaram-se os fluxos turísticos via aeroporto de Fortaleza, com voos diretos para destinos como Miami, Orlando, Paris e Amsterdã. Em outras capitais internacionais, como Lisboa, Madrid e Paris, os Hubs aéreos funcionam como meios dinamizadores de fluxos de pessoas.

Para Paula (2012, p. 177):

O aumento significativo da movimentação de passageiros após a construção do AIPM vem ratificar a importância dos fixos (portos e aeroportos) na dinamicidade dos fluxos (pessoas, mercadorias, investimentos e etc.) que repercutem diretamente no ritmo de transformações impostas à paisagem natural, bem como na sua antropização. Esse novo dinamismo aeroportuário conduziu a adaptações substantivas da rede viária, designadamente através da construção de novas vias de acesso interligando o aeroporto ao litoral, onde se concentra a maior parte dos equipamentos hoteleiros da cidade.

Conforme Araújo (2016), o turismo de Fortaleza é litorâneo e urbano, e agrega as áreas centrais já consolidadas estruturalmente no rol das principais áreas turísticas, havendo uma relevante relação entre as áreas de expansão urbana e as áreas turísticas. Dessa forma, Araújo (2016, p. 06) discute que "compreender as relações e dinâmicas socioespaciais decorridas na cidade é o ponto inicial e crucial de toda a análise espacial do espaço turístico metropolitano", considerando a influência de Fortaleza na atividade turística da Região Metropolitana.

Essa influência evidencia-se ainda mais considerando a recente pesquisa realizada pelo IBGE (2020), a qual apontou que a rede da Metrópole de Fortaleza abarca diversas Unidades da Federação, total e parcialmente, situando-se no Ceará, Piauí e Maranhão, chegando à parte do oeste pernambucano, Tocantins e Pará, sendo a quinta colocada em termos de área, com 765 mil km², e tendo 630 Cidades sob sua influência.

Surgiram no litoral de Fortaleza novos negócios voltados à priorização dos espaços à beira-mar, incluindo empreendimentos imobiliários (residências, hotéis, restaurantes, bares e barracas de praia), que ocupam, dentre outras áreas, as praias, as dunas e os manguezais. Uma ocupação muitas vezes não sustentada do meio e causando impactos, como a canalização dos riachos urbanos e a fixação das dunas costeiras, o que pode contribuir para intensificação da erosão costeira, além da produção de esgoto doméstico e de ligações clandestinas à rede de drenagem pluvial, comprometendo a qualidade da água marinha de Fortaleza e afetando a balneabilidade das praias (Paula, 2012).

A cidade (ou cidade-metrópole) de Fortaleza possui algumas características peculiares, conforme aponta Araújo (2011, p. 68):

a) Apesar de não existirem resorts, os meios de hospedagem em Fortaleza são consolidados, com grande capacidade de leitos. Esses meios de hospedagem integram-se à dinâmica da cidade, estando a maioria deles localizada nas imediações da Avenida Beira Mar, Aldeota, Meireles, com algumas poucas exceções na Praia do Futuro e em alguns bairros comerciais.

b) A maioria dos agentes turísticos localiza-se em Fortaleza (nos planos internacional, nacional e local) e faz estratégias privilegiando o turismo na cidade. Essa lógica vem se consolidando com mais firmeza nos últimos tempos em virtude da escolha das cidades-sedes da Copa do Mundo de 2014. 
c) A cidade de Fortaleza não é exclusivamente turística; tem uma dinâmica de capital cearense e, assim, possui estabelecimentos de diversas demandas e peculiaridades, além do restrito patrimônio histórico e cultural, mas suficientes para formar pacotes turísticos no Centro e adjacências: museus, centros históricos, mercados e centros, ou seja, alternativas de atrativos para eventuais passeios turísticos.

d) Os governos em suas diversas escalas investem consideravelmente em infraestrutura na cidade, aliando ao turismo uma política de planejamento da Região Metropolitana de Fortaleza. Tal afirmativa leva a se pensar: planejamento do turismo, ou da cidade pelo turismo?

e) O marketing e a propaganda de Fortaleza (por ser capital do Ceará) é uma variável relevante no planejamento turístico do Ceará, sendo consolidado ao longo dos governos estaduais, com destaque também para as praias de Cumbuco (na RMF) e Jijoca de Jericoacoara ("paraíso perdido" do Ceará).

Araújo (2016) revela que, apesar de políticas públicas e investimentos privados diversos, os espaços litorâneos possuem características diferenciadas, não sendo homogêneos quanto ao turismo, pois são motivados por particularidades e pela lógica desigual da produção espacial capitalista, o que diferencia o uso dos espaços litorâneos de Fortaleza. Dantas (2011, p. 82) corrobora o pensamento de Araújo (2016) ao afirmar que há uma "divisão clássica da cidade em duas partes, a leste e a oeste: a primeira mais bem cuidada e a segunda 'abandonada' pelo poder público”.

A orla turística de Fortaleza é composta por trechos da Praia de Iracema, Praia do Meireles, Praia do Mucuripe e Praia do Futuro. Iniciando uma discussão individualizada de cada uma dessas áreas, Paiva (2014) diz que a parte correspondente à Praia de Iracema, embora com pouca extensão, possui usos e características morfológicas bastante diversas, muitos dos quais originados do processo de evolução histórica do bairro.

As transformações ocorridas na Praia de Iracema são um forte indicativo da urbanização turística em Fortaleza, revelando as várias faces desse processo, principalmente pelo fato do espaço de ter se tornado uma mercadoria, submetendo-se a um ciclo de ascensão e declínio. As marcas desse processo de turistificação na orla da Praia de Iracema ainda são visíveis na presença de equipamentos turísticos, como meios de hospedagem, bares e restaurantes. A ocupação da orla concentra ainda edificações multifamiliares verticais, reforçando a valorização imobiliária desse trecho litorâneo. Atualmente, está em fase de construção um grande equipamento turístico no local, o Aquário do Ceará, cujas obras estão paralisadas, como tentativa de criar um novo ciclo de valorização turística da Praia de Iracema (Paiva, 2014).

Na extensão da Avenida Beira Mar, onde se localiza a Praia do Meireles, verifica-se uma dinâmica voltada para os mercados imobiliário e turístico, através das redes hoteleiras instaladas e da construção de edifícios multifamiliares, muitas vezes utilizados como segunda residência. Revela-se, assim, o papel preponderante do mercado no processo de urbanização turística da Beira Mar, uma vez que o mesmo se utiliza da infraestrutura instalada e das belezas naturais (defronte ao mar) para criar produtos turísticos (Paiva, 2014).

Referente à orla do Mucuripe, Paiva (2014) diz que aí há usos conflitantes em relação à atividade turística pelo fato deste trecho estar vinculado às atividades do porto, historicamente consideradas áreas degradadas pelo porte e tipo de atividades que concentram. Muito embora o trecho compreendido entre o Iate Club e o porto tenha sido apropriado por edifícios multifamiliares destinados à habitação e à hotelaria, o porto é um ponto final da expansão da configuração espacial nos moldes da orla turística da Beira-Mar. Há de se considerar ainda a existência de um porto de ancoragem de jangadas relacionado à atividade de pesca tradicional que, junto com as ocupações irregulares e favelizadas, são exemplos de resistência da comunidade local à apropriação do litoral pelo mercado imobiliário e turístico.

Partindo para a caracterização da urbanização turística da Praia do Futuro, Paula (2012) discute que se trata de espaço que une a modernidade dos grandes condomínios com a simplicidade das comunidades tradicionais, onde a antropização também se revela nos equipamentos urbanos voltados ao turismo e ao lazer e as dunas, características da área, são ocupadas pelas mais diversas formas de moradias. Essa urbanização foi responsável pela alteração do sistema natural de drenagem e degradação do solo, além da impermeabilização das dunas.

Dantas (2011, p. 64) traça um perfil dos frequentadores da Praia do Futuro: 
Os usuários frequentam barracas na praia, que oferecem bebidas, alimentos e diversão para toda sorte de clientes, denotando uma especialização espacial - as barracas situadas do Vicente Pinzón até o cruzamento das avenidas Zezé Diogo e Santos Dumont são frequentadas por clientes menos privilegiados, enquanto as situadas após este cruzamento tendem a especializar-se no atendimento de fluxo de lazer das classes abastada e média, bem como de representativo fluxo turístico.

A região atualmente passa por uma recuperação imobiliária, onde novos empreendimentos estão sendo construídos, além de novos investimentos em desenvolvimento urbano, com novas vias de acesso (Paula, 2012), e a recente reforma do calçadão, inclusa no projeto de requalificação da área, cujas obras foram entregues no ano de 2014.

Porém, permanecem indefinidas as questões relacionadas à ocupação irregular das barracas de praia, algumas com ampla estrutura (contendo, por exemplo, piscinas, lojas, áreas de recreação para crianças), na Praia do Futuro, motivo de disputas judiciais que se prolongam há vários anos sem se chegar a uma solução que garanta o uso sustentável da praia para turistas e comunidade local.

Com o evento da Copa do Mundo de 2014 e outros sucessivos, Araújo (2016) discute que a Região Metropolitana de Fortaleza, especialmente o seu litoral, recebe cada vez mais subsídios para o planejamento de políticas públicas voltadas à promoção da mais recente fase da urbanização-metropolização de Fortaleza e espaços subjacentes.

\subsection{Florianópolis}

Florianópolis, localizada na parte central do litoral catarinense, é a segunda destinação turística mais importante do estado de Santa Catarina. Com grande riqueza ambiental e paisagística, a Ilha de Santa Catarina tem cerca de $42 \%$ de seu território $\left(189,42 \mathrm{~km}^{2}\right)$ como Área de Preservação Permanente - APP. O conjunto dessas áreas se expande por toda a Ilha, caracterizando a ocupação urbana e turística (Pereira, 2003; Reis, 2010).

Além do patrimônio natural rico em biodiversidade, a Ilha de Santa Catarina e o continente próximo destacam-se também pelas marcas da colonização açoriana ainda presentes no seu cotidiano, seja na gastronomia, no sotaque, na arquitetura, no artesanato, nas festas e nas tradições dos imigrantes do Arquipélago dos Açores chegados há séculos atrás (Pereira, 2003). Machado (2000, p. 185) acrescenta que "a sua localização na costa próxima ao continente tem facilitado a gradual integração do município/região nos diversos circuitos de relações sócio-espaciais”.

Campos, Corrêa e Nascimento (2019) reforçam que a açorianidade, conceito utilizado para enfatizar a identidade cultural de origem açoriana, passou também a influenciar o processo socioeconômico regional. Esse movimento se intensificou principalmente após a década de 1980, havendo uma generalização sociocultural, voltando-se para interesses econômicos que muitas vezes espetacularizam a cultura local, em especial com a expansão da atividade turística.

Em sua face metrópole, Florianópolis se insere em um contexto estadual específico, com diversas Capitais Regionais presentes em Santa Catarina, às quais se conectam as cidades de menor hierarquia e, a partir dessas Capitais Regionais, estabelece-se a influência de Florianópolis. A participação da renda produzida por Florianópolis perfaz apenas 14,1\% do PIB produzido por toda sua região de influência. É a menor participação do núcleo dentre as redes urbanas desse nível hierárquico, revelando uma melhor distribuição territorial da geração de riqueza entre as cidades que compõem a rede urbana (Ibge, 2020).

As limitações impostas à ocupação humana pelos ecossistemas costeiros (manguezais, dunas, elevações, etc.), associadas ao processo histórico de ocupação de seu território, têm contribuído de forma expressiva para os impactos ambientais em Florianópolis. Esses ambientes vêm sendo sistematicamente transformados, seja em decorrência das práticas agrícolas iniciadas com a colonização, seja com o ciclo econômico consolidado a partir dos anos 1970, quando o turismo associado à formação de balneários e à construção civil levou à urbanização de extensas faixas do seu território (Reis, 2010).

Silveira e Rodrigues (2015) argumentam que, por conta de sua configuração físico-espacial, Florianópolis não segue o 
mesmo padrão de aglomeração urbana de outros municípios litorâneos brasileiros. Seus núcleos urbanos estão dispersos no território formado pela Ilha de Santa Catarina, onde comunidades de pescadores que habitam a região desde os séculos anteriores, foram transformadas em balneários para a prática do lazer e do turismo litorâneo, como é o caso da Praia do Jurerê.

Pereira (2010), Reis (2010) e Mamigonian (2011) discutem que, até mais da metade do século passado, a representatividade de Florianópolis no contexto catarinense limitava-se às suas funções político-administrativas como capital do estado. A capital, pela sua posição geográfica, era isolada do resto do estado, com acessos precários e não pavimentados, até mesmo nas vias de acesso ao Aeroporto Hercílio Luz. Percebe-se hoje, por outro lado, uma dinamização responsável pela ampliação de sua participação regional baseada no setor terciário, principalmente no turismo.

É preciso considerar ainda que em Santa Catarina o processo de urbanização das últimas décadas vem estimulando a conurbação dos núcleos urbanos, particularmente os do litoral Centro-Norte, no qual está inserido Florianópolis, situação esta potencializada pelos crescentes fluxos turísticos, o que elevou, dentre outros fatores de ordem socioeconômica, a capital à condição de metrópole. A exploração do litoral tem levado à criação de inúmeros balneários, consolidando, de forma praticamente contínua, extensa faixa urbanizada, implicando em alterações socioambientais (Pereira, 2010; Reis, 2010).

O desenvolvimento do turismo em Florianópolis foi conduzido pelo dinamismo do mercado, no qual a especulação imobiliária é vetor das novas formas de uso e ocupação do espaço urbano. Assim, locais com características rurais foram loteados, urbanizados e vendidos para a construção de condomínios de segunda residência, resorts, hotéis, pousadas e de outros equipamentos de turismo. Nas últimas duas décadas, a urbanização turística na Ilha de Florianópolis se intensifica e, em muitos lugares, novas edificações foram construídas para atender à crescente demanda de turistas, transformando rapidamente as localidades onde antes vivia a população local, formada principalmente por comunidades de pescadores (Silveira \& Rodrigues, 2015).

Apesar da forte influência da atividade hoteleira, é a segunda residência que consolida os tecidos urbanos que ocupam intensamente planícies quaternárias e avançam por sobre encostas. Loteamentos costeiros levam a um processo de verticalização e adensamento (como em Canasvieiras, Jurerê e Ingleses), onde grandes empreendimentos têm se instalado, sinalizando a entrada progressiva de capital estrangeiro no ramo turístico-imobiliário (Reis, 2010).

O aumento da população e dos movimentos migratórios em Florianópolis, associados ao crescimento do setor imobiliário e do turismo e à expansão intraurbana, dentre outros fatores, consolidaram a área conurbada de Florianópolis. A expansão dessa mancha urbana mostra-se contínua da parte insular da capital às terras circunvizinhas do continente (Biguaçu, São José e Palhoça). Essa importância regional atribuída ao desenvolvimento de Florianópolis minimizou a influência das capitais dos estados vizinhos sobre Santa Catarina, além de ter se transformado num importante polo receptor de turistas nacionais e estrangeiros (Sugai, 2002; Pereira, 2010).

Nas últimas temporadas de veraneio, a demanda vem aumentando em relação à oferta de atrativos e equipamentos em alguns espaços, como na porção Norte da Ilha (que envolve as praias de Canasvieiras, Ingleses, Jurerê, Ponta das Canas), caracterizando-se por um turismo de massa facilitado pelos bons acessos. As faixas de areia nas praias são disputadas entre construções inadequadas, banhistas e vendedores ambulantes (Silveira \& Rodrigues, 2015).

Silveira e Rodrigues (2015) consideram que é preciso reconhecer melhorias urbanas para Florianópolis proporcionadas pelo crescimento do turismo, como o aumento na oferta de serviços e de equipamentos urbanos e a implantação de um moderno sistema viário e de transportes. Machado (2000) acrescenta que há significativos avanços no tocante à presença de novos estilos de vida e usos de padrões tecnológicos identificados, sobretudo, em obras de construção civil, estabelecimentos comerciais e de serviços (shoppings, marinas, clubes, hotéis, etc.) e meios de comunicação, os quais fazem com que o potencial turístico local assuma certas identidades com características de grandes polos receptores e até de nível internacional. Como exemplos dessas novas identidades, tem-se o novo Aeroporto Internacional de Florianópolis, que se 
destaca no cenário do turismo como um dos aeroportos mais modernos da América Latina, dispondo de uma gama de serviços que atende aos perfis mais diversos de turistas e está posicionando Florianópolis como um dos principais destinos brasileiros, como receptor e distribuidor de fluxos turísticos.

Por outro lado, esse crescimento urbano vem acompanhado de muitos impactos negativos ao meio ambiente. As áreas naturais ainda preservadas correm o risco de ter o mesmo quadro dos locais já saturados e degradados pela atividade turística. Logo, esse crescimento urbano e o rápido aumento populacional vêm se desenvolvendo, conforme Reis (2010), à margem de um processo de planejamento voltado a um projeto coletivo de cidade, dada a fragilidade dos planos e a inexistência de formas de controle, levando a inúmeros problemas, como: baixa capacidade de abastecimento de água potável, comprometimento da balneabilidade, degradação de ecossistemas naturais, contaminação dos rios e do mar, falta de infraestrutura de saneamento e transporte.

Pereira (2003, pp. 120-121) destaca que:

O desenvolvimento turístico, além de acelerar a expansão urbana, causa profundas alterações na configuração histórico-espacial da cidade, gerando processos de urbanização diferenciados e grandes impactos sobre os traços culturais e padrões de comportamento das populações de origem açoriana ainda conservados pelas comunidades nativas. A atratividade turística fica comprometida pelo adensamento populacional registrado em alguns balneários, como é o caso de Canasvieiras, Ingleses e Lagoa da Conceição, enquanto empreendimentos turísticos de grande porte criam loteamentos reservados às classes altas, implantados a partir da década de 80 em grandes glebas de terras (Jurerê Internacional e Praia Brava). O turismo torna-se o grande vetor do crescimento urbano de Florianópolis e projeta Santa Catarina nacionalmente, apesar dos limitados investimentos públicos e da precariedade do planejamento para o setor.

Reis (2010) discute ainda que a questão da delimitação entre área urbanizada e ambiente natural é tema bastante relevante na atualidade da ocupação urbano-turística da Ilha. Em direção à encosta, o crescimento urbano-turístico é responsável por ocupações agressivas tanto aos ecossistemas naturais quanto ao ambiente urbano. A retirada da cobertura vegetal, a impermeabilização dos terrenos por construções e a consequente aceleração da velocidade das águas têm provocado impactos ambientais graves, com deslizamentos de encostas. Tais riscos sugerem a preservação das encostas, bem como uma clara delimitação entre a ocupação urbana e áreas de preservação.

Silveira e Rodrigues (2015, p. 10) afirmam que:

Esta concentração de equipamentos turísticos visa exclusivamente atender à crescente demanda turística, enquanto a população local pouco tem se beneficiado das melhorias urbanas. E, quanto maior a demanda turística da localidade, maior a diversidade de equipamentos instalados na mesma. As áreas Central e Leste da ilha são as que possuem melhor oferta de equipamentos urbanos. Em seguida, a região Norte da Ilha também pode ser destacada. Por sua vez, a região Sul, de ocupação mais recente, os equipamentos urbanos ainda são insuficientes. E, as áreas de encostas da ilha, que estão densamente ocupadas pela população local, não possuem o mínimo de equipamentos e/ou infraestrutura, evidenciando uma crescente segregação socioespacial.

Nessas circunstâncias, Machado (2000) revela que o estado realiza aplicações de investimentos cada vez mais densos (infraestruturas, prestação de serviços, financiamentos, etc.) nos lugares onde a sua função pode gerar poder de barganha em favor dos emergentes segmentos de classes sociais que se apresentam como "novos" ocupantes dos tradicionais territórios açorianos.

Com uma dinâmica ocupacional seletiva e qualitativa, sendo capital administrativa do estado e polo turístico nacional, com potencial de atratividade para atividades de alta tecnologia, reforçada pela atuação de diversas universidades existentes, Florianópolis desponta, a cada ano, como Polo Metropolitano Regional (Campos, 2009). 


\section{Considerações Finais}

O processo de urbanização nos municípios de Fortaleza e Florianópolis teve o turismo litorâneo como um dos seus principais fatores de desenvolvimento. Os fluxos turísticos começaram a gerar necessidades antes não existentes: aeroportos e vias de acesso precisaram ser construídos e ampliados; cresceram os investimentos no setor hoteleiro, assim como os investimentos imobiliários voltados para o turismo de segunda residência; a infraestrutura urbana como um todo se modificou para atender aos interesses do turismo, ou seja, especialmente do capital deste setor econômico.

A expansão urbana promovida pelo turismo é tanta que o limite entre o que é urbano e rural já não é mais algo exato, entendendo que a atividade turística demanda infraestruturas, equipamentos e serviços diversos, sobrepondo-se o urbano nessa relação. Isso se reflete também no processo de conurbação com cidades vizinhas, principalmente em relação ao crescimento de bairros de classe baixa na periferia, em virtude do alto custo da moradia em áreas nobres ao turismo. Tal expansão espacial, que, apesar de ser um fenômeno ocasionado por diversos fatores, intrínseca ao fenômeno da metropolização nestas duas capitais estudadas, torna os destinos turísticos cada vez mais globalizados, o que também explica o crescimento do segmento de turismo urbano.

É nesse contexto que se deve questionar até que ponto o urbano traz consigo um sinônimo de avanço. Como fica a situação das comunidades locais diante das intervenções promovidas por aqueles que querem (a qualquer custo) fazer do turismo uma fonte inesgotável de riquezas? Em que medida essas modificações urbanas estão respeitando os limites ambientais?

Torna-se imperioso pensar e planejar sobre as implicações que podem ocorrer diante da alteração do espaço motivada pelo turismo ou por qualquer outra atividade econômica. O desenvolvimento tem muitas faces e, quando se oculta alguma(s) dela(s), os prejuízos ambientais muitas vezes são irreversíveis.

Sugerem-se propostas para trabalhos futuros que incorporem a investigação de intervenções da urbanização turística no litoral (assim como em áreas rurais) e seus impactos, de modo a se estudar alternativas de uso e ocupação do solo sustentáveis, que garantam qualidade de vida para os residentes locais e satisfação na experiência do turista.

\section{Referências}

Allis, T., \& Vargas, H. C. (2015). Turismo urbano em São Paulo: reflexões teóricas e apontamentos empíricos. Turismo em Análise, $26(3)$, $496-517$.

Alves, G. P., Botezelli, L., Botan, M. C. C. O., \& Sant'Anna, D. O. Periferização, qualidade ambiental urbana e percepção dos moradores em cidades médias: estudo de caso no município de Itajubá/MG. Research, Society and Development, 10(1), 1-18.

Araújo, E. F. (2011). As políticas públicas e o turismo litorâneo no Ceará: o papel da Região Metropolitana de Fortaleza. Sociedade e Território, 23(2), 57-73.

Araújo, E. F. (2016). Turismo: entre o urbano e o metropolitano alguns apontamentos socioespaciais em Fortaleza-Ce. Geosaberes, 7(12), 1-10. Barbosa, J. M. \& Paula, D. P. (2020). Intervenções do processo de urbanização turística na Praia de Iracema, Fortaleza (CE). Geosaberes, 11, $551-571$.

Bastos, J. M. (2020). Urbanização, comércio e pequena produção mercantil pesqueira na Ilha de Santa Catarina. Em Lins, H. N., Bastos, J. M., Santos, M. A. (Org.) \& Cherem, R. M., Ensaios sobre Santa Catarina (pp. 127-140). Florianópolis, SC: Letras Contemporâneas.

Campos, E. T. (2009). A expansão urbana na Região Metropolitana de Florianópolis e a dinâmica da indústria da construção civil (Tese de doutorado). Universidade Federal de Santa Catarina, Florianópolis, Santa Catarina, Brasil.

Campos, N. J., Corrêa, M. K., \& Nascimento, L. P. (2019). Povoamento vicentista e açoriano-madeirense. Em Santa Catarina, Atlas geográfico de Santa Catarina: população - fascículo 3. (2a. ed) (pp. 55-69). Florianópolis, SC: Editora UDESC.

Correa, L. H. S. (2016). A segunda residência como indutora da urbanização em áreas litorâneas na contemporaneidade. Geo UERJ, (28), 291-307.

Dantas, E. W. C. (2011). Mar à vista: estudo da maritimidade em Fortaleza. (2a. ed.). Fortaleza, CE: Edições UFC.

Ferreira, A., Rua, J., \& Mattos, R. C. (2014). A metropolização do espaço, gestão territorial e relações urbano-rurais: algumas interações possíveis. Geo UERJ, 2(25), 477-504.

Instituto Brasileiro de Geografia e Estatística. (2020). Regiões de influência das cidades: 2018. Rio de Janeiro, RJ: IBGE. 
Research, Society and Development, v. 10, n. 12, e48101220152, 2021

(CC BY 4.0) | ISSN 2525-3409 | DOI: http://dx.doi.org/10.33448/rsd-v10i12.20152

Luna, S. V. O falso conflito entre tendências metodológicas. Cad. Pesq., (66), 70-74.

Machado, E. V. (2000). Florianópolis: um lugar em tempo de globalização (Tese de doutorado). Universidade de São Paulo, São Paulo, Brasil.

Mamigonian, A. (Org.) (2011). Santa Catarina. Estudos de geografia econômica e social. Florianópolis, SC: GCN/CFH/UFSC.

Minayo, M. C. S. (Org.). Pesquisa Social. Teoria, método e criatividade (18 ed.). Petrópolis, RJ: Vozes.

Moleiro, D. F. O planeamento do turismo urbano com vista à sustentabilidade - Uma revisão de literatura. Research, Society and Development, 9(8), 1-30.

Paiva, R. A. (2014). Os impactos da "urbanização turística" no litoral de Fortaleza: fragmentação e diferenciação socioespacial. Anais do XI Seminário da ANPTUR, Fortaleza, Ceará, Brasil, 11

Paula, D. P. (2012). Análise dos riscos de erosão costeira no litoral de Fortaleza em função da vulnerabilidade aos processos geogênicos e antropogênicos (Tese de doutorado). Universidade do Algarve, Algarve, Portugal.

Pereira, R. M. F. A. (2003). Formação sócio-espacial do litoral de Santa Catarina (Brasil): gênese e transformações recentes. Geosul, 18(35), 99-129.

Pereira, R. M. F. A. (2010). Expansão urbana e turismo no litoral de Santa Catarina: o caso das microrregiões de Itajaí e Florianópolis. Interações, 12(1), 101111.

Pérez, S. L. C. (2018). Análisis del turismo urbano como sistema funcional. Caso de estúdio: Turismo urbano em Quito, Ecuador. Territorios em Formación, (13), 116-133.

Reis, A. F. (2010). Preservação ambiental no contexto urbano: cidade e natureza na Ilha de Santa Catarina. Estudos Urbanos e Regionais, 12(1), 45-61.

Rizzo, P. M. B. (2013). O planejamento urbano no contexto da globalização: caso do Plano Diretor do Campeche em Florianópolis, SC (Tese de doutorado). Universidade Federal de Santa Catarina, Florianópolis, Santa Catarina, Brasil.

Santos, M. (1993). A urbanização brasileira. São Paulo, SP: Ed. Hucitec.

Santos, M. (2006). A Natureza do Espaço: Técnica e Tempo, Razão e Emoção. (4a. ed.). São Paulo, SP: Editora da Universidade de São Paulo.

Silveira, M. A. T., \& Rodrigues, A. B. (2015). Urbanização turística no Brasil: um foco em Florianópolis - Santa Catarina. Via Tourism, (7), 1-13.

Souza, E. C. (2007). Praia de Iracema: fatores de estagnação de um espaço turístico à beira-mar (Dissertação de mestrado). Universidade Federal do Ceará, Fortaleza, Ceará, Brasil.

Sugai, M. I. (2002). Segregação silenciosa: investimentos públicos e distribuição sócio-espacial na área conturbada de Florianópolis (Vol. 1) (Tese de Doutorado). Universidade de São Paulo, São Paulo, Brasil.

Verde, M. R. V., Santana, L. S. G., Almeida, P. N. L., Reis, R. B., Mello, M. M. C., \& Cavalcante, M. M. Expansão urbana e redução de áreas verdes em Salvador/BA: o caso do Parque São Bartolomeu. Research, Society and Development, 9(10), 1-23.

Zanela, C. C. (1999). O discurso sobre o turismo na Ilha de Santa Catarina (1983-1998) (Dissertação de mestrado). Universidade Federal de Santa Catarina, Florianópolis, Santa Catarina, Brasil. 